\title{
JURY CHALLENGES, CAPITAL PUNISHMENT, AND LABAT V. BENNETT: A RECONCILIATION
}

Reasoning that one who opposes the death penalty may deny the state an impartial trial, most American jurisdictions sustain a challenge for cause to a prospective juror with such scruples. Recent decisions, attempting to ensure that the jury truly represents a "cross-section of the community," have, however, suggested that due process may be denied when an identifiable class of the community is summarily excluded from the jury cross-section. The legitimacy of this theory may well be tested in the Supreme Court this term, as two cases raise the question whether capital punishment objectors are such a class. This comment 'seeks to assess the validity of the due process approach in the context of traditional justifications for the challenge to the capital punishment objector.

Judar UDGMENT by one's social "peers" is constitutionally impermissible in this country. Unlike the English nobleman who at one time could require that his case be heard before the House of Lords, members of which were his actual peers, ${ }^{1}$ the defendant in the United States faces a jury of his constitutional peers; i.e., a jury drawn from a "cross-section of the community." 2 The sole opportunity provided a litigant to tailor this cross-section for his particular case is the exercise of challenges to remove certain prospective jurors. Although a limited number of potential jurors may be excused by each party on peremptory challenges, exercisable for any or no reason

${ }^{2}$ M. Cottu, ON the Administration of Criminal Justice in England 185-87 (1822). The privilege of a "peer jury" existed, however, only for those charged with a felony, and was not unattended by disadvantage. The Lords were both judge and jury, and no challenge to a trier was allowed. Id. "A single historical fact, will illustrate the danger to which Peers were liable to be exposed by such an unfair mode of procedure. At the trial of the Protector, Somerset, Northumberland, Northampton, and Pembroke sat among his Judges." J. Fortescue, DE Laudibus LeQum ANGLiaE 88 n.a (1825).

2 See, e.g., Brown v. Allen, 344 U.S. 443, 474 (1953); Smith v. Texas, 311 U.S. 128, 130 (1940); Labat v. Bennett, 365 F.2d 698, 719-20 (5th Cir. 1966); Allen v. State, 110 Ga. App. 56, 62, 137 S.E.2d 711, 715 (1964). Possibly the best known expression of the cross-section principle is found in Fay v. New York, 332 U.S. 261, 299-300 (1947) (Murphy, J., dissenting): "[T]here is a constitutional right to a jury drawn from a group which represents a cross-section of the community. And a cross-section of the community includes persons with varying degrees of training and intelligence and with varying economic and social positions. Under our Constitution, the jury is not to be made the representative of the most intelligent, the most wealthy or the most successful, nor of the least intelligent, the least wealthy, or the least successful. It is a democratic institution, representative of all qualified classes of people." 
whatever, additional prospects may be eliminated by a successful challenge for cause. Questioning at voir dire is, therefore, primarily directed toward uncovering in the prospective juryman some disqualifying partiality which will provide cause for his dismissal. The generally established rule in this country is that a prospect's adherence to conscientious scruples concerning capital punishment constitutes a complete disqualification from jury service. While resting ostensibly on the objector's probable partiality, the rule implies that capital punishment objectors are not a proper element for representation in the community cross-section which constitutes the jury. Recently, however, the cross-section concept has undergone significant revision, and now represents a severe limitation on the jury selection process. The conflict between this expanding definition of "cross-section" and the present prevalence of challenges for cause to capital punishment objectors raises the principal question to which this comment is addressed: What degree of opposition to capital punishment must be revealed by a prospective juror on voir dire before he may successfully be challenged for cause without violating the constitutional right of the defendant to a jury composed of a cross-section of the community?

Development of concepts pervading current jury practice. Any discussion of proper jury composition necessarily must ascertain the nature of the protection sought through the constitutional guarantee of trial by jury. An attempt to trace the history of the jury to its origin as a means of ascertaining its initial function yields inconclusive results. ${ }^{3}$ Indeed, the trial of citizens by other lay citizens historically has had such widespread employment as to make it seemingly impossible to discern from which germinal concept our system descended. ${ }^{4}$ Jurors at first were witnesses, selected for their knowledge of the dispute and the disputants. ${ }^{5}$ Gradually the function of

${ }^{3}$ See, e.g., W. Forsyth, History of Truad BY JURY 1-6 (1852); Grooms, The Origin and Development of Trial by Jury, 26 ALA. LAw. 162 (1965).

4 Compare J. Proffatr, Trial BY JURY \$2 (1877), with McCready, Challenging Jurors, 58 Dick. L. REv. 384 (1954), and Kun, Validity of the Unanimous Verdict Requirement, 22 PA. B.A.Q. I5 (1950). Greek, Roman, Scandinavian, and Anglo-Saxon elements of trial, for example, have been speculatively identified in the history of the English jury system. See generally J. Profratr, supra $§ \S 1-22$. Whatever its origins, it is clear that trial by jury was instituted in England as an alternative to trial by combat and compurgation. See id. $\$ \S 12,23$.

5. Profratr, supra note 4, $\$ \$ 29,32$. "It was, therefore, incumbent on those who 
the jury changed to that of trier of fact, ${ }^{6}$ and jurors were then selected for their lack of knowledge or bias regarding the case.

The importance that early America attached to trial by jury is reflected in the Bill of Rights. Concerned that article III, giving the Supreme Court the power to review questions of law and fact, was an abridgment of the finality of a jury's findings of fact, the colonists' insistence upon clarification produced the sixth and seventh amendments. ${ }^{7}$ The seventh amendment concerns civil suits, and provides that "the right of trial by jury shall be preserved ...." The sixth amendment stipulates that "in all criminal prosecutions, the accused shall enjoy the right to a speedy and public trial, by an impartial jury ...." However, these constitutional provisions are binding only on the federal government, as jury trial has not been held a

discharged this office [of juror] to make themselves acquainted with the matter in controversy by personal inspection and inquiry before the day of trial so as to be possessed of the requisite knowledge for forming a judgment." $I d$. $\S 32$, at 48 . For what a judge considered a mistaken verdict, the jury and the litigant in whose favor the questionable verdict was rendered were subject to attaint. Webster, Jury Sentencing -Grab-Bag Justice, 14 Sw.L.J. 221, 223 (1960). Attaint was not a light chastisement, but involved turning the attained one's wife and children out of doors, destroying his home and land, and uprooting his trees. J. Fortescue, supra note 1, at 90-91. The justification for attaint was that, as jurors were witnesses, a mistaken verdict could be the product only of willful perjury or corruption. J. Proffarr, supra note $4, \$ 32$. Attaint, operating thus as a brake on the independence of the jury, persisted until 1670. In that year, in the famous cause of Bushnell's Case, it was established that judges might no longer punish jurors because their verdicts were displeasing. Webster, supra at 223. By Blackstone's time, attaint was an antiquated concept. "But such a remedy as this [attaint] laid the injured party under an insuperable hardship, by making a conviction of the jurors for perjury the condition of his redress.

"The judges saw this; and very early, even for the misbehavior of jurymen, instead of prosecuting the writ of attaint, awarded a second trial: and subsequent resolutions, for more than a century past, have so extended the benefit of this remedy, that the attaint is now as obsolete as the trial by battel [sic] which it succeeded: and we shall probably see the revival of the one as soon as the revival of the other." 3 Blackstone, Commentaries 389 . With the end of attaint, the capacity of judges to tyrannize over juries was vitiated. In their own area of deliberation, then, the decision of the jurors was final. For a discussion of the apportionment of responsibility between judge and jury in eighteenth century libel and sedition cases, for example, see Trial of JoHn Stockdale; for a Libel on the House of Commons (Shorthand by Joseph Gurney 1790) [hereinafter cited as TrIal of STOckdal.E].

$a$ "Only by a slow and imperceptible process running throughout five centuries does the jury come to be solely triers of fact upon the evidence presented. The change is far advanced in the 1500 s, but the following century will close before it can be looked upon as in all respects complete, and the employment of the jury can be definitely regarded under all circumstances as a mode of trial rather than a mode of proof." R. Mirllar, Grvil Procedure of the Trial Court in Historical Perspective $20-21$ (1952) (footnote omitted).

7 Story, Commentaries on the Constitution \$\$918-19 (1833); see J. Proffatt, supra note 4 , at $121-26$. 
fundamental right of the people "inherent in the concept of ordered liberty," secured by the fourteenth amendment from state abridg. ment. ${ }^{8}$ Nevertheless, every state constitution provides for trial by jury. ${ }^{9}$

Requirement of jury unanimity. One incident of jury trial which advances its continued claim as a protector of the people's liberties is the requirement of unanimity in verdicts. ${ }^{10}$ Operating under such a requirement, a jury is prohibited by the sheer weight of its own membership from taking precipitate action. The opinion of no member of the jury may be disregarded if a unanimous verdict must be returned, and therefore discussion of dissenting views is assured.

The unanimity requirement was established in the fourteenth century, ${ }^{11}$ possibly in satisfaction of the fiction that the jurors spoke for the country in pronouncing their decision, and the country could speak with only one voice.12 There was no conflict between insistence on unanimity and the function of the jurors as witnesses. As witnesses, they were supposed to know the truth of the matter in

${ }^{8}$ Palko v. Connecticut, 302 U.S. 319, 324-25 (1937) (dictum) (sixth amendment); accord, Fay v. New York, 332 U.S. 261, 288 (1946) (seventh and relevant portion of sixth); Pearson v. Yewdall, 95 U.S. 294, 296 (1877) (seventh). The reason that a jury trial has not been held to be "fundamental" is that it is but one guilt-determining process, and others, equally fair, could be devised. Palko v. Connecticut, supra at 325. The restraint of the Supreme Court in not imposing a uniform method of trial upon the states has been favorably commented upon. E.g., 33 VA. L. REv. 655 (1947).

- See Irvin v. Dowd, 366 U.S. 717, 721-22 (1961), citing Columbia University LeGis. lature Drafting Research Fund, Index Digest of State Constitutions 578.79 (1959).

${ }^{10}$ In the federal courts, unanimity in civil verdicts is required by the seventh amendment. Thompson v. Utah, 170 U.S. 343, 350 (1898); American Publishing Co. v. Fisher, 166 U.S. 464, 468 (1897). The sixth amendment compels unanimity as to guilt in criminal verdicts. Maxwell v. Dow, 176 U.S. 581, 586 (1900). However, these amendments do not apply to the states, and the Supreme Court has indicated that a state court practice of accepting majority verdicts would not violate fourteenth amendment due process requirements. Jordan v. Massachusetts, 225 U.S. 167, 176 (1912). See generally Orfield, Verdict in Federal Criminal Cases, 15 MERGER L. REV. 378 (1964).

11 R. MillaR, supra note 6 , at 21 \& n.18. Concerning unanimity in British trials, Blackstone observed that: "This necessity of a total unanimity seems to be peculiar to our own constitution; or, at least, in the nembda or jury of the antient [sic] Goths, there was required (even in criminal cases) only the consent of the major part; and in case of an equality, the defendant was held to be acquitted." 3 Blackstone, stlpra note 5 , at 376 .

In "old times," upon the disagreement of a single juror, the verdict of eleven jurors was taken and the standout was thrown into prison. However, in the reign of Edward III it was established that no verdict could be returned by fewer than twelve jurors. W. Forsyth, supra note 3 , at 241 .

12 Webster, supra note 5, at 223. 
issue, and any disagreement among them was thought to indicate that the dissenters were merely being obstreperous. ${ }^{13}$ In the United States, the sixth and seventh amendments incorporated the common law characteristics of jury trial at the time of their adoption, ${ }^{14}$ with the result that a federal court verdict, to be constitutionally valid, must be accepted by all the jurors. ${ }^{15}$ However, since jurymen no longer serve as witnesses, the traditional reasons for unanimity no longer apply, and the wisdom of continuing to require it is often questioned. ${ }^{16}$

The extension of the unanimity requirement beyond the threshold question of guilt to the issue of punishment was established in Andres $v$. United States. ${ }^{17}$ Petitioner Andres was tried in a federal court for first degree murder under a federal statute which gave the jury the power to exercise its discrtion in imposing life imprisonment or death upon conviction. ${ }^{18}$ A conviction and death sentence were affirmed by the Court of Appeals for the Ninth Circuit. The Supreme Court, noting that Congress had given the jury the discretion of life or death in order to "limit the severity of the old law,"10 held that the proper exercise of this discretion under the sixth and seventh amendments demanded unanimity as to

13 W. ForsYTh, supra note 3 , at 244; J. Proffatr, supra note $4, \S \S 77-78$. The temptation to engage in obstinate behavior was sharply curtailed by the custom of confining the jury without meat, drink, fire, or candle until agreement was reached. See 3 BrAckstone, supra note 5, at 375; W. Forsytm, supra note 3, at 411 . This procedure produced the happy situation in which the unanimity which was thought to be a philosophical necessity was also a practical certainty.

14 See Baltimore \& C. Line v. Redman, 295 U.S. 654, 657 (1935) (seventh amendment); Patton v. United States, 281 U.S. 276 (1930) (sixth amendment).

${ }^{15}$ See note 10 supra.

${ }^{10}$ See, e.g., Kun, supra note 4, where the author notes the inconsistency of requiring a twelve member jury to achieve unanimity on guilt, whereas a panel of judges trying the case could decide by a majority vote. The author suggests that if a jury were unable to agree on the major charge in a criminal case, but could muster a significant majority, such as $3 / 4$ or $10 / 12$, on a lesser degree of guilt, they should be permitted to render that verdict. The retention of the unanimity requirement can be best understood from a consideration of the present day functions of the jury, discussed in text accompanying notes $26-38$ infra.

17333 U.S. 740 (1948).

${ }^{18}$ Act of Mar. 4, 1909, ch. 321, $\$ 330$, 35 Stat. 1152 (now 18 U.S.C. $\$ 1111$ (1964)): "In all cases where the accused is found guilty of the crime of murder in the first degree, or rape, the jury may qualify their verdict by adding thereto 'without capital punishment'; and whenever the jury shall return a verdict qualified as aforesaid, the person convicted shall be sentenced to imprisonment for life."

10333 U.S. at 748. The Court found "expressions [in the legislative history] which indicate" that Congress's purpose was to mitigate the former statutory scheme which made death mandatory upon a finding of guilt. Id. 
all issues-"character or degree of the crime, guilt and punishment."20 Applying this standard to the statute, the Court found that proper construction would require unanimity on either capital punishment or life imprisonment.21 So construed, the statute was constitutionally acceptable. However, the conviction was reversed for failure properly to instruct the jury. In the Court's opinion, the instructions of the trial judge possibly left the jurors with the impression that if unanimity were not reached on the lesser sentence of life imprisonment, capital punishment must necessarily be imposed upon conviction. Therefore, at the present time, no verdict may be returned in a federal court in a capital case by a jury divided on punishment, and a similar rule is followed in many, though not all, state courts. ${ }^{22}$

The jury as reflector of contemporary community standards. The functions of the jury cannot be ascertained by examination of its historical origins. ${ }^{23}$ Rather, its present purposes inhere in the mode of its accepted operation. One task of the jury is that of fact finding, and the unanimity requirement assures rigorous examination into the merits of opposing evidence. In applying the law to its factual conclusions, however, the jury may also weigh certain extra-judicial considerations. ${ }^{24}$ This function, perhaps appropriately referred to as the jury's mitigation of laws and penalties, ${ }^{25}$ flows from

${ }^{20} \mathrm{Id}$.

${ }^{21}$ Id. at 749. The necessary result of the Andres holding is that a jury agreed on guilt but divided on punishment is a hung jury.

${ }^{22}$ For a listing of the states which require unanimity on punishment see the appendix to the opinion of Frankfurter, J., in Andres v. United States, 333 U.S. 740, 767-70 (1948). Florida, for example, requires a majority vote to recommend mercy upon a finding of guilt of a capital crime. In a recent decision, where the jury split 6 to 6 on the question of whether to make the recommendation, the Florida Supreme Court held that no violation of due process resulted from imposition of the death pen. alty. Watson v. State, 190 So. 2d 161 (Fla. 1966).

${ }^{23}$ See notes 3-4 supra and accompanying text.

24 See generally H. KALVEN \& H. ZeISEL, ThE AMERICAN JURY (1966). In conducting a broad study, authors Kalven and Zeisel compared jury decisions on actual cases with the response which the judge acknowledged he would have made had he lieard the case alone, in an effort to isolate areas of judge-jury disagreement. In examining the areas of disagreement discovered, several theories were developed which might explain what non-judicial factors actually influence a jury in its decision. The authors concluded that jurors are sometimes motivated by a feeling that the defendant has been punished enough; that the threatened punishment is too severe; that the victim engaged in "contributory negligence"; that the law of self-defense allows too limited a response to an attack victim; or that the offense is too trivial to be visited with the sanctions of the criminal processes.

${ }^{25}$ Indeed, there is some indication that during the nineteenth century it was be- 
the panel's power to render a general verdict in complete disregard of the judge's instructions and the law. ${ }^{28}$ Resident in this power of the jury is an effective safeguard against a despotic legal system. ${ }^{27}$

The jury's mitigation of laws and penalties may take one of several forms. Thus, it may be a refusal to apply the full rigor of the law to a given defendant; ${ }^{28}$ it may involve rejection of the law itself; or it may be a reaction against the punishment to be inflicted upon conviction. Examples of jury rejection of law itself are plentiful. English anti-duelling laws, ${ }^{29}$ colonial taxation and trade regulation laws, ${ }^{30}$ and prohibition $^{31}$ are outstanding illustrations of legislative

lieved that the jurors had a moral responsibility under "natural law" to follow their consciences rather than the instructions of the judge. See Note, The Changing Role of the Jury in the Nineteenth Century, 74 YALE L.J. 170, 172-73 (1964).

${ }_{20}$ Generally, in criminal cases a jury verdict of acquittal terminates the defendant's exposure to possible punishment. While the prosecution may request a new trial based on errors committed by the court, thereby subjecting the defendant to an additional risk of punishment, a verdict of acquittal rendered by the jury after an error-free trial will not be overturned, even if the verdict is contrary to the evidence. The finality of the verdict is its essential element, and is attested to from earliest common law times by the existence of coercive measures, such as attaint, to persuade the jurors to change the verdict, as only they could do so. See note 5 supra.

${ }^{27}$ See, e.g., TrIal of Stockdale, supra note 5, at 191-92; Comment, Consideration of Punishment by Juries, 17 U. Crr. L. REv. 400, 401 n.5 (1950); Note, The Changing Role of the Jury in the Nineteenth Century, 74 YALE L.J. 170, 171 (1964). The institution of the jury has long excited praise bordering on the adulatory. E.g., 3 BLAckSTONE, supra note 5 , at 381 .

${ }^{28}$ As an example of jurors' refusal to apply the full rigor of the law, the tendency of the jury with respect to some defendants is to treat them with more leniency than would a judge. Examples of factors exciting the jurors' sympathy toward the individual defendant are the defendant's overall good appearance; his physical handicaps; his reputation as an honest, hardworking man; his ignorance; his remorse; his goodlooking wife; his pregnant wife; his crying wife; his military service; or his mother's poverty. One judge, in response to the questionnaire used by the Kalven study, surmised that a lenient verdict was produced by these circumstances of the defendant, accused of embezzlement: "Lady; alien; Christmas time." H. KaLven \& H. ZEIser, supra note 24, at 202. See generally id. at 193-218. Kalven and Zeisel found that not only were jurors more sympathetic to certain defendants, but that their reactions could quantitatively be categorized among defendants differing in sex, race, and age. $I d$. at 211, Table 65.

20 "The law of England is clear and explicit, that death occasioned by a duel is murder; and yet, notwithstanding the numerous trials which have taken place for this offence, how few have been the convictions. ... [T] hey [the jurors] have determined that killing another in a fairly-fought duel is not murder." W. FORSYTH, supra note 3 , at 264 (emphasis in original).

${ }^{80} \mathrm{After}$ the French and Indian Wars, when the British attempted to introduce in the colonies new laws on taxation and trade regnlation, convictions of Americans by American juries were so scarce that British officials were compelled to turn for more favorable treatment to admiralty courts and courts martial. Powell, Jury Trial of Crimes, 23 WASH. \&. LEE L. REv. 1,3 (1966).

${ }^{a 1}$ Id. at 7 . Jurors may also reject the law concerning the elements of a crime, particularly those based on legal fictions. For example, the jury may refuse to accept 
edicts effectively nullified through jury resistance to their implementation. Current studies indicate that American jurors tend to take a more lenient view than do judges of game laws, liquor laws, gambling, and drunken driving. ${ }^{32}$ In the jury's nullification of these crimes through its refusal to convict is found the same jury independence that characterized earlier periods, though the absence of more widespread jury intransigence may be viewed as an indication of the public acceptability of present law. Jury rejection of legally prescribed punishment has a similar history. In the early nineteenth century in England, there were in excess of two hundred capital crimes. In reaction to this severity of punishment, juries frequently refused to convict at all..$^{33}$ Today, if each element of a crime is made out at trial but the jury convicts the defendant of a lesser crime, or acquits him, it is plain that the jury's wish is that the defendant not suffer the consequences attendant the graver conviction, ${ }^{34}$ a jury behavior frequently encountered in capital cases. ${ }^{35}$

Whenever the jury gives rein to its own feelings about the defendant and the law, it is clear that extra-judicial standards are being applied. Yet when unanimity must be reached among twelve people chosen from a cross-section of the population, personal whimsy can hardly be the "standard" to which the jury is appealing. It must of necessity be a community standard, reflecting to some extent the mores of the population at large from which jury membership is drawn. The consistent application of a community standard which rejects a given law leaves the legislature powerless to do anything save repeal or modify that law. Juries may thus have a direct impact on legislation. The validity and desirability of this impact have long been recognized. Over one hundred years ago it was written,

When in respect of any class of offences the difficulty of obtaining convictions is at all general in England, we may loold it as an axiom, that the law requires amendment. Such conduct in juries is the silent protest of the people against its undue severity. . .

the fiction of implied intent in the felony-murder rule. Kalven \& Zeisel, The American Jury and the Death Penalty, 33 U. CHr. L. REv. 769, 775 (1966).

32 See H. KALVEN \& H. ZeISEL, supra note 24, at 286-97.

${ }^{33}$ Id. at 311 n.7; cf. White, Origin and Development of Trial by Jury, 29 TENN. L. REv. 8, 18 (1961).

${ }^{34}$ See Comment, Compromise Verdicts in Criminal Cases, 37 NEB. L. REv. 802, 808-10 (1958).

35 See J. Kennedy, On the Law and Practice of Jurues 45 (1826); Comment, 12 N.Y.L.F. 688, $691 \&$ n.40 (1966). 
'[I]t has this important and useful consequence, that laws totally repugnant to the feelings of the community for which they are made, cannot long prevail in England.'36

This constant tailoring of the law to contemporary community standards is undoubtedly one of the basic contributions of the jury system. It thus becomes increasingly important that jury representation not be denied to representative and responsible community viewpoints-in short, that the jury continue to represent a crosssection of the community-lest this tailoring function be partially disabled.

The function of voir dire. One brake on the representative nature of the jury is the exercise of challenges to individual jurors at voir dire-a pre-trial period during which prospective jurors are questioned to uncover matters which might disqualify them to hear the case at hand. The exact scope of the early English use of voir dire questioning, while presumably broad, is not precisely recorded. ${ }^{37}$ However, one operative limitation on inquiry was the mandate that the prospect be asked nothing the answer to which would tend to dishonor him. ${ }^{38}$ In America, on the assumption that the juror's

\footnotetext{
${ }^{30} \mathrm{~W}$. Forsyth, supra note 3 , at 431 , citing LORD JOHN Russell, ESSAY ON ENGLISH GOVERNMENT 393 (emphasis added).

${ }^{37}$ In England the jurors themselves were not required to answer questions as to their qualifications before challenge. Instead, the challenge was required to be made and then supported through subsequent voir dire examination. $R$. Millar, supra note 6 , at 289-91. The rule forbidding questioning until after challenge has continued up to the present day in England, where there is no voir dire comparable to that employed in the United States. There, juries are assembled with few challenges. Id. at 291-92; Comment, The Jury Voir Dire: Useless Delay or Valuable Technique, 11 S.D.L. REv. 306, 308 (1966); see Moore, Voir Dire Examination of Jurors, 16 GEo. L.J. 438, 445 (1928). There is no doubt that the English practice of disallowing voir dire until after challenge was that which first prevailed in America. See, e.g., Crippen v. People, 8 Mich. 117, 126 (1860); King v. State, 6 Miss. (5 How.) 730, 734 (1841); State v. Flower, 1 Miss. (Walker) 318 (1829); State v. Creasman, 32 N.C. 285 (1849). In State v. Baldwin, 1 Tread. (S.C.) 289, 292-93 (1813), the suggestion was made that the existence of bias and partiality is itself something which might tend to the prospective juror's disgrace, and therefore it may not be inquired into prior to challenge. However, a theory of constructive challenge seems to have arisen, allowing questioning before a challenge was actually directed. See People v. Rendigs, 123 Misc. 32, 46, 205 N.Y.S. 133, 145 (Ct. Gen. Sess. 1924); People v. Larubia, 69 Hun. 197, 23 N.Y.S. 579 (Sup. Ct.), aff'd, 140 N.Y. 87, 35 N.E. 412 (1893).

${ }^{38}$ So inclusive were the early restrictions on questioning that an inquiry as to whether the prospect had formed an opinion as to the guilt or innocence of the accused was thereby barred, M. CoTTu, supra note 1, at 82; J. KENNEDX, supra note 35, at 103, for to believe one's neighbor guilty before the trial of his cause was an unbecomingly gratuitous expression of hostility, Joy, Challenges to Jurors in Criminal Cases, in 40 LAw Library 164, 194 (Wharton ed. 1843).
} 
competency was being tried, the prospective juror himself has been deemed a witness to whom leading and direct questions could be posed. ${ }^{30}$ However, the questioning could not approximate crossexamination, ${ }^{40}$ and certain inquiries were forbidden. Parallelling English practice, American courts rejected any question the response to which might lead to the prospect's infamy or self-incrimination. Initially, questions as to his belief in the prisoner's guilt or innocence were proscribed, ${ }^{41}$ but that particular limitation has long since fallen away. Instead, the inquiry is directed to the tenacity with which the juror would hold to the opinion when confronted with law and evidence. ${ }^{42}$ Moreover, inquiry is directed to the prospect's prejudice against a particular law, ${ }^{43}$ but he may not generally be asked whether he thinks a crime should be visited with a punishment different from that which the law prescribes. ${ }^{44}$ Despite these restrictions on voir dire in American courts, it may be said that a broad range of permissible questioning remains, controlled chiefly by the discretion of the trial judge. 45

Once voir dire questioning has uncovered facts relevant to juror qualifications, challenges may be directed by the court or by coun$\mathrm{sel}^{46}$ to prospects who are, for one reason or another, objectionable. If the challenge is upheld by the judge, the challenged prospect is

30 Martin v. State, 16 Ohio 364, 369 (1847).

${ }^{40}$ Commonwealth v. Burroughs, 145 Mass. 242, 243-44, 13 N.E. 884, 886 (1887); R. MIILAR, supra note 6, at 293-97. The apparent theory for denying questioning which approached the depth of cross-examination was that the juror would thereby be com. pelled to be a witness against himself. The proper course for counsel was to introduce other competent evidence supporting the disqualification of the juror. See Commonwealth v. Burroughs, supra at 243,13 N.E. at 886.

41 See generally J. Proffatr, supra note 4, \$\$ 195-97; note 38 supra.

42 See J. Proffatr, supra note 4, §\$ 186-87.

${ }^{48}$ See, e.g., State v. Normandale, 154 La. 523, 97 So. 798 (1923); Hamilton v. State, 74 Tex. Crim. 219, 168 S.W. 536 (1914). But cf. Ideal Laundry \& Dry Cleaning Co. v. Mackowiak, 83 lnd. App. 1, 143 N.E. 614 (1924).

14 See, e.g., Commonwealth v. Buzzell, 33 Mass. (16 Pick.) 153 (1834).

45 See, e.g., United States v. Carabbia, 381 F.2d 133 (6th Cir.), cert. denied, 389 U.S. 1007 (1967); Commonwealth v. Bonomi, 335 Mass. 327, 140 N.E.2d 140 (1957); State v. Bunk, 4 N.J. 461, 73 A.2d 249, cert. denied, 340 U.S. 839 (1950). See generally Note, 58 YArE L.J. 638 (1949). See also Stout, The Examination of Prospective Jurors in Capital Cases, 29 TEXAs L. REv. 34 (1950) (procedure in Texas); Thompson, Challenging the Individual Juror in Nevada Criminal Cases, 12 NEv. S.B.J. 163 (1947).

${ }^{16}$ Various jurisdictions differ in the allocation between court and counsel of responsibility for questioning. For the history and present status of this apportionment, in. cluding citations to state statutes governing who interrogates, see Note, Voir Dire Examination-Court or Counsel?, 11 ST. Lovis U.L.J. 234, 235.38 \& nn.25.32 (1967). See also 10 Mercer L. Rev. 210, 211 (1958). 
excused. One category of challenges comprises peremptory challenges, of limited number, which enable the parties to remove any potential juror for whom, irrespective of the reason, they have formed a distrust. ${ }^{47}$ On the other hand, challenges for cause are intended to test a juror's fitness to hear the case. At common law, challenges for cause were of four types: challenge propter honoris respectum, which enabled either party to remove a lord of parliament and, incidentally, enabled the lord to excuse himself; challenge propter defectum, for deficiency in some area of necessary qualification, such as citizenship; challenge propter affectum, which concerned bias and partiality; and challenge propter delictum, for previous conviction of crime or misdemeanor. ${ }^{48}$ The category presently encompassing challenges for cause to capital punishment objectors is propter affectum, which was in turn divided into principle challenge and challenge to the favor. ${ }^{49}$ While the reasons for the various types of challenges are cur-

7 At common law a felony defendant was usually allowed 35 peremptories, on a very general theory that no man should be judged by another of whom he is for any reason suspicious. See Comment, Voir Dire-Prevention of Prejudicial Questioning, 50 MINN. L. REv. 1088, 1091 (1966). This apparent tenderness for the defendant provides a corollary benefit to the state. Surely the defendant will more readily accept the justice of the verdict, and will be more receptive to rehabilitation, if he feels that it is the community which has judged him, and not twelve individuals toward one or more of whom he has some antipathy.

A discussion of peremptory challenges is not pursued in this comment. Though such challenges may be made with no cause assigned, they are limited in number, and the full utilization of the nnmber allowed will not usually serve grossly to disfigure a prospective jury panel. It should be noted, however, that the Supreme Court has indicated that perversion by the prosecution of the purposes of the peremptory challenge, as to exclude Negroes from juries, is not beyond the reach of the equal protection clause. Swain v. Alabama, 380 U.S. 202, 223-24 (1965). In Swain, however, the record was held inadequate to show such discriminatory use of the challenge. Id. at 224.

483 Brackstone, supra note 5, at 361-64; M. Cotru, supra note 1, at 75-82.

19 Gronnds for principle challenge were those which indicated such a relationship to the parties or to the case as to presage a manifest partiality on the part of the prospect for one party over another. Examples are kinship within certain degrees and dependency of certain types. The principle challenge raised a qnestion of law. Challenges to the favor were directed at jurors who were suspected of having some prejudice in favor of one party not amounting to that which would be grounds for a principle challenge, the presence or absence of such prejudice being a question of fact. Examples of this partiality are given in J. KENNEDY, supra note 35, at 95.96, 98.

All the challenges discussed in the text are those to the polls, or to individual jurors. In addition, it was possible to level a challenge to the array, which charged some impropriety in the collection of the panel which derogated from the acceptability of the entire group. For a discussion of all branches of the challenge for cause see J. Proffatr, supra note $4, \S \S 148,166,167$. For a list of causes adequate 
rently viable, the distinction between principle challenges and challenges to the favor is now largely disregarded, ${ }^{50}$ as the common law classifications have been subsumed under the more general heading of challenges for cause. The continued vitality of the challenge for cause is a constitutional necessity in the United States, as an incident of the assembly of an impartial jury. ${ }^{51}$ Therefore, although usually the categories of challenge for cause are statutorily defined, any other objections running to the lack of impartiality on the part of a prospective juror may similarly be asserted. ${ }^{52}$

\section{Capital Punishment Objection as Ground for Challenge for Cause}

It is not clear when challenges for cause to capital punishment objectors came into use, ${ }^{53}$ but by 1850 at least, the practice was well established. ${ }^{54}$ Possibly the objection originated in solicitude for the

to support challenges principle and to the favor see The Conductor Generalis 211. 14 (1792) and Joy, supra note 38, at 164-70.

${ }^{20}$ See, e.g., O'Fallon Coal Co. v. Laquet, 198 111. 125, 64 N.E. 767 (1902).

${ }^{-1}$ As an impartial jury is a due process requirement, and as the challenge for cause is directed at the removal of jurors who show evidence of bias, the challenge continues to be a constitutionally necessary element of trial by jury. J. Profratr, supra note 4 , $\$ 187$ at $242 \mathrm{n} .2$, and cases cited therein. The indications of bias which may be uncovered upon voir dire are infinitely varying, and the discretion of the trial judgc governs in the matter of whether the bias, of whatever kind, is of such magnitude as to disqualify the juror from impartial consideration of the casc and the parties involved. See note 45 supra.

${ }^{52}$ Comment, The Jury Voir Dire: Useless Delay or Valuable Teelinique, 11 S.D.L. REv. 306, 329 (1966).

${ }^{63}$ Authority on the early English practice does not mention challenges hascd on scruples against the death penalty. It has been noted, however, that any question tending to the juror's disgrace was not allowed on voir dire, and that any inquiry concerning pre-formed opinion as to the guilt or innocence of the accused was held to be such a question. See note 41 supra and accompanying text. If the operative concept of "dishonor" were so broadly construed, it seems possible that an indica. tion by a juror that he had scruples about capital punishment would similarly have been considered to disgrace him, on the theory that he had indicated that he was so cavilling a fellow that he would refuse to apply the law of the land.

${ }^{5}$ See Gross v. State, 2 Ind. 329 (1850); Martin v. State, 16 Ohio 364 (1847). A recent case, holding such exclusions constitutional under a statute providing the jury with a choice between life or death, is State v. Childs, 269 N.C. 307,152 S.E.2d 453 (1967), noted in 45 N.C.L. REv. 1070 (1967). Iowa and South Dakota are the only two states which do not allow challenges for cause to the capital punishment ohjector. E.g., State v. Lee, 91 Iowa 499, 60 N.W. 119 (1894); State v. Garrington, 11 S.D. 178, 76 N.W. 326 (1898).

Recently, Supreme Court review was sought in a case in which the defendant alleged that the prosecutor was insincere in averring that the death penalty would be sought by the state, and in excusing 59 of 119 prospective jurors for capital punisliment objections. People v. Miller, 245 Cal. App. 2d 112, 138-39, 53 Cal. Rptr. 720, 736-37, 
religious or moral convictions of the prospective juror.55 Indeed, one court explained such challenges as premised upon mental incompetence, reasoning that a juror who was conscientiously opposed to the imposition of the death penalty was, as to that issue, insane and therefore unfit for service. ${ }^{56}$ In light of the requirement of unanimity in verdicts, the challenge was almost a mechanical necessity, for when a finding of guilt carried an automatic death penalty, a juror opposed to capital punishment might be predisposed to acquit. The resulting denial of a fair trial to the state might justify the exclusion of all capital punishment objectors if such a scruple were so strongly held as to make the juror incapable of hearing and deciding a capital case according to the court's instructions on the law. However, there were and are varying degrees of opposition to the death penalty represented in community thought, ${ }^{57}$ not all of which would produce an unfair decision. Yet, it has never been the usual practice to direct extensive inquiry to a juror to ascertain the depth of his conviction on this subject. Indeed, if a prospective juror states some scruple against capital punishment, it has been held no error for the judge to excuse him immediately, with no

cert. granted, 389 U.S. 968 (1967). In granting certiorari, however, the Supreme Court did not agree to hear this issue. 389 US. at 968 . However, in two cases the Court has granted certiorari to consider a straightforward attack on the constitutionality of the exclusion itself. People v. Witherspoon, 36 Ill. 2d 471, 224 N.E.2d 259 (1967), cert. granted, 389 U.S. 1035 (1968); State v. Bumpers, 270 N.C. 521, 155 S.E.2d 173 (1967), cert. granted, 389 U.S. 1034 (1968).

${ }^{6}$ See, e.g., State v. Vick, 132 N.C. 995, 43 S.E. 626 (1903); State v. Bowman, 80 N.C. 432 (1878).

50 "A man who would disregard his oath [as a juror] to save his conscience, is not fit to be trusted anywhere. One who has such strong prejudices, that he can not do what he knows to be right, when it confiicts with his peculiar theories, or whose mind is so obscured by. his own peculiar notions, that he can, with a conscience void of offense, make the law of his country bend to his own will and accommodate its provisions to his own visions of morality, ought never to be allowed to sit as a juror. If insane on the particular subject to be inquired into, he is, as to that subject, no better than if altogether demented." Martin v. State, 16 Ohio 364, 369 (1847).

${ }^{67}$ Judicial notice has been taken of the degrees of opposition to capital punishment. See Turberville v. United States, 303 F.2d 411, 419 (D.C. Cir.), cert. denied, 370 U.S. 946 (1962). In 1960 a Gallup Poll conducted nationwide showed $51 \%$ of the nation favoring capital punishment. In 1958 a Roper Poll indicated that $47 \%$ favored capital punishment, $50 \%$ opposed it, and $8 \%$ [sic] were undecided. Brief for Appellant at 31, Witherspoon v. Illinois, 36 Ill. 2d 471, 224 N.E.2d 259 (1967), cert. granted, 389 U.S. 1035 (1968). These figures indicate that a broadly phrased question concerning opposition to capital punishment could be expected to disqualify from jury service approximately half of the United States' population. Thus, the impact of such a question upon the "cross-section" required for the jury is obvious. 
further, more particularized, examination. ${ }^{58}$ An atypical case is People v. Stewart, ${ }^{\text {,9 }}$ in which a prospective juror was asked on voir dire if he had any conscientious opinions which would preclude his joining in a guilty verdict when the crime was a capital offense. Answering that he was opposed to capital punishment on principle, he was excused on challenge. The reviewing court drew a distinction between conscientious opinions, which it posited were personal and "irresponsible to all human tests and standards," and convictions based on principle, which were said to be responsive to reasoned argument. ${ }^{60}$ As the operative statute called only for the exclusion of those with conscientious opinions which would preclude a finding of guilt, exclusion of the challenged juror for possession of opinions of principle was error. The court adopted the position that " $\mathrm{h}] \mathrm{is}$ opinions of what the law ought to be, would not disqualify him from obeying it as it is." ${ }^{1}$ The more widely accepted line of cases, however, adopts the opposing view that any evidence of such scruples will support a challenge for cause. ${ }^{62}$ Further, no jurisdiction requires for disqualification that a juror state that he could, under no circumstances, impose a capital sentence. ${ }^{63}$

The necessity for qualifying the jury on the capital punishment issue, insofar as that issue bears on the jurors' willinguess to convict, would seem to be obviated by the modification of many state criminal statutes to allow the jury to choose death or life imprisonment upon conviction. ${ }^{64}$ Since under the new statutes a juror, upon a

${ }^{58}$ See People v. Hoyt, 20 Cal. 2d 306, 125 P.2d 29 (1942); People v. Goldenson, 76 Cal. 328, 19 P. I6I (1888); Russell v. State, 53 Miss. 367 (1876); State v. McIntosh, 39 S.C. 97, 17 S.E. 446 (1893). But see Bell v. State, 9I Ga. 15, I6 S.E. 207 (1892). Nevertheless, sometimes the question is asked whether the scruples would prevent the juror from returning a verdict in accordance with the law and the evidence. Some jurisdictions may disqualify him even though he says his verdict would be uninfluenced by his opinions. See People v. Riser, 47 Cal. 2d 566, 305 P.2d I (1956), cert. denied, 353 U.S. 930 (1957); State v. Williams, 50 Nev. 271, 278, 257 P. 619, 621 (1927). In others, such a response would qualify him to serve. Stratton v. People, 5 Colo, 276 (1880); Williams v. State, 32 Miss. 389 (1856).

607 Cal. 141 (1857).

${ }^{\circ 0} \mathrm{Id}$. at 144.

${ }^{61} \mathrm{Id}$. at 141 .

62 See note 58 supra.

${ }^{63}$ See State v. Scott, 243 La. 1, 141 So. $2 d 389$ (1962); Rhea v. State, 63 Neb. 461, 88 N.W. 789 (1902). In Scott the prospect stated that the crime would have to be "pretty serious" before he could return the death penalty. His removal on challenge was held proper.

o4 See generally Knowlton, Problems of Jury Discretion in Capital Cases, $10 \mathrm{I} U$. PA. L. REv. 1099 (1953). All state statutes governing the imposition of capital punish- 
finding of guilt, may vote to impose life imprisonment which is both a valid legal alternative and, to him, a morally acceptable one, there would seem to be no reason for blanket exclusions of capital punishment objectors. Indeed, the statutory modification seemingly has removed from challenges to such objectors the historic justification that opposition to a mandatory death penalty might force an objectorjuryman to acquit, for the new forms sever the issue of guilt from that of punishment. Surprisingly, the addition of a statutory choice of life or death typically has brought no change whatever in the approach taken to juror challenges. ${ }^{85}$ The rationale supporting this result is well illustrated in People v. Riser, ${ }^{66}$ a 1956 decision of the California Supreme Court. Petitioner Riser was convicted of first degree murder, and a sentence of death was imposed by a jury from which all who professed conscientious objection to the death penalty had been removed. Petitioner alleged that removal of these persons was unnecessary, since the applicable statute disqualified only those whose conscientious opinions would preclude a finding of guilt. Apparently in belief that conscientious scruples would continue to influence an objector's vote on punishment, the California court held the continuation of the old challenge procedure to be proper, stating that " $[\mathrm{t}]$ he statute calls for the exercise of a legal discretion [by the jurors], not for the unswerving application of views formulated before the trial that will compel a certain result no matter what the trial may reveal." ${ }^{\text {" }}$

ment, whether automatically or on the recommendation of the jury, are cited in Oberer, Does Disqualification of Jurors for Scruples Against Capital Punishment Constitute Denial of Fair Trial on Issue of Guilt?, 39 TEXAS L. REv. 545, 546 n.2, 550 n.29 (1961).

Authority exists for the proposition that the jury at common law has always had the power to recommend mercy. See 31 Mass. L.Q., Oct. 1946, at 60. However, that recommendation carried no authority.

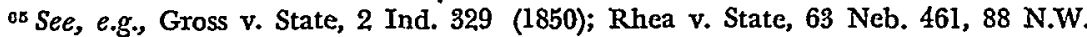
789 (1902). Compare State v. Vick, 132 N.C. 701, 43 S.E. 626 (1903), with State v. Childs, 269 N.C. 307, 152 E.E.2d 453 (1967). Possible reasons for the continuation of the disqualification are discussed by Knowlton, supra note 64, at 1106. Knowlton, summarizing approaches taken by the courts to this question, concludes that continuation of the challenge is felt to be necessary lest the jurors decide cases upon their own convictions rather than upon the facts adduced, or lest the state be required to abandon a possible death verdict. Id. at 1106-07.

oo 47 Cal. 2d 566, 305 P.2d 1 (1956), cert. denied, 353 U.S. 930 (1957).

${ }^{87}$ Id. at 575,305 P.2d at 7. This approach, however, fails to recognize the varying degrees of opposition to death penalties felt by the individual prospective juror. See text accompanying note 73 infra. If the evil sought to be avoided by the challenge is the "unswerving application of views formulated before the trial," it would seem pertinent to inquire more deeply into the strength with which those views are held. 
Similar results have been reached in the federal courts. In United States $v$. Puff, ${ }^{68}$ decided under a statute giving the jury the choice between life and death, the Court of Appeals for the Second Circuit held that the petitioner could have suffered no prejudice through the removal of capital punishment objectors, even if done without sufficient cause, if there were on the actual jury no unqualified person. ${ }^{69}$ Furthermore, it was reiterated that detailed questioning to uncover degrees of opposition would be unproductive, as the prospective juror would no doubt be both uncomfortable and unsuccessful in identifying the circumstances, if any, in which he would impose the ultimate penalty. The Puff court, however, spoke more to the issue of the mechanical problems involved in allowing jury service by objectors than to any theoretical necessity for removing them. Thus, because Andres required unanimity of the jury on punishment as well as guilt, disagreements among jurors some of whom refused to impose death could lead to hung juries and to "practical immunity from murder."70 This result was said to be insupportable.

Similarly, in Turberville $v$. United States, ${ }^{71}$ the petitioner, although not given a capital sentence, alleged that the excuse on challenges for cause of those jury prospects who stated opposition to capital punishment had denied him trial by a true cross-section of the community. Relying expressly on the Puff decision, the court rejected his contention, ${ }^{72}$ observing initially that not all those who feel some opposition to capital punishment are necessarily disqualified from service, as "[t]he nub of disqualification on this ground is whether the opposition is of such nature as to preclude an impartial judgment on the fact and the law of the case to be tried."'73 However, it was not error for the judge in his discretion to sustain challenges to jurors whose removal was not reasonably required, for "among those who remained were none who suffered . . . an impediment to proper service."74

\footnotetext{
${ }^{88} 211$ F.2d 171 (2d Cir.), cert. denied, 347 U.S. 963 (1954), noted in 40 IowA L. REv. 374 (1955).

${ }^{80} 211$ F.2d at 185.

${ }^{30} \mathrm{Id}$.

71303 F.2d 411 (D.C. Cir.), cert. denied, 370 U.S. 946 (1962).

72 $I d$. at $419-20$.

${ }^{73} \mathrm{Id}$. at 419 .

74 Id.
} 
The Turberville approach presents the reasoning which sustains the widespread use of challenges to remove capital punishment objectors. The discretion of the judge governs the point at which a prospect will be deemed disqualified. ${ }^{75}$ Although this discretion is subject to review for abuse, relief on review is usually limited to cases in which a challenge for cause was improperly denied, resulting in the inclusion of a biased juror. ${ }^{76}$ An abuse which produces the unnecessary elimination of qualified jurors has been largely without effective remedy, as the challenge procedure has been traditionally viewed as a time of rejection and not of selection. ${ }^{77}$ The essential justification for elimination of capital punishment objectors, based upon the Andres unanimity requirement, is that the mechanics of jury operation would be partially disabled were an objector to sit on the jury. ${ }^{78}$ Nevertheless, as most of the statutes governing punishment for grave offenses allow the jury to select either a life or death sentence, the inclusion of some individuals who disfavor the death penalty in all but dire cases might have the compensating benefit of guaranteeing a wholesome and vigorous discussion of the alternatives. However, the general practice of not inquiring into the depth of a juror's scruples but excluding him upon his acknowledgment of any scruples at all is often given the theoretical support mentioned by the Puff and Turberville courts; i.e., so long as the jurors actually trying the case are impartial, it is of no consequence that other, similarly qualified, prospects were mistakenly rejected. In short, only a showing of actual prejudice to the defendant by the exclusion of jurors would justify reversal of his conviction.

\section{Constitutional Limitations on JuRy Exclusions}

Although traditionally the states have exercised great autonomy over jury selection procedures, they have nonetheless operated under constitutional mandates which forbid the exclusion of certain classes from the jury box. ${ }^{79}$ Until very recently, the due process clause of

${ }^{75}$ See note 45 supra.

${ }^{70}$ The reversal is necessary because the presence of a biased juror is a violation of due process. This general principle was recognized in United States v. Puff, $211 \mathrm{~F} .2 \mathrm{~d}$ 171, 185 (2d Cir.), cert. denied, 347 U.S. 963 (1954), and People v. Stewart, 7 Cal. I4I (1847).

77 See, e.g., Smith v. State, 5 Okla. Crim. 282, 284, 114 P. 350, 351 (1911) (dictum).

${ }^{78}$ See note 70 supra.

${ }^{70}$ See, e.g., Hernandez v. Texas, 347 U.S. 475 (1954) (exclusion of those of Mexican 
the fourteenth amendment imposed few limitations on jury composition, as it forbade only the use of triers of fact who would not afford a fair trial, ${ }^{80}$ judged against concepts of fundamental fairness. Therefore, the due process clause of its own force would outlaw trial by a lynch mob, ${ }^{81}$ but not the erroneous exclusion of a juror for cause if his replacement were "impartial." However, the more delicate question of the relative fairness or favoritism shown different defendants by juries of varying compositions has most often been determined under equal protection principles. ${ }^{82}$

As part of a Reconstruction amendment, the equal protection clause in its classic application safeguarded the rights of Negroes to a trial before a jury from which members of that race had not arbitrarily been excluded. ${ }^{83}$ Not long after its passage, the clause was utilized to guard the rights of other minority groups, and the exclusions of determinate religious groups, political parties, races, and women were successfully attacked by defendants of the class alleged to have been excluded. ${ }^{84}$ Reversal of the conviction of a defendant who could prove deliberate and invidious discrimination ${ }^{85}$ against his class was founded on the theory that there was such a high probability of damage to the defendant resulting from the class exclusions as to make a showing of actual prejudice unnecessary. The removal of the prejudice requirement, however, was allowed only in cases in which the defendant and the excluded jurors were of a class

descent); Kentucky v. Powers, 139 F. 452 (C.C.E.D. Ky. 1905) (those of a specified political party); State v. Guirlando, 152 La. 570, 93 So. 796 (1922) (dictum) (1talians); Juarez v. State, 102 Tex. Crim. 297, 277 S.W. 1091 (1925) (Roman Catholics).

${ }^{80}$ See, e.g., Tumey v. Olnio, 273 U.S. 510 (1927); Moore v. Dempsey, 261 U.S. 86 (1923); Frank v. Mangum, 237 U.S. 309 (1915) (dictum); Jordan v. Massachusctts, 225 U.S. 167 (1912) (dictum).

81 Moore v. Dempsey, 261 U.S. 86 (1923).

so See, e.g., Eubanks v. Louisiana, 356 U.S. 584 (1958); Strauder v. West Virginia, 100 U.S. 303 (1880).

${ }^{88}$ E.g., Eubanks v. Louisiana, 356 U.S. 584 (1958); Neal v. Delaware, 103 U.S. 370 (1880); Strauder v. West Virginia, 100 U.S. 303 (1880).

84 See cases cited note 79 supra.

${ }^{35}$ The difficulty of proving invidious discrimination against a class has long been acknowledged. See, e.g., Note, The Defendant's Challenge to a Racial Criterion in Jury Selection: A Study in Standing, Due Process and Equal Protection, 74 YALE L.J. 919, 935-37 (1965). The courts luave accommodated defendants facing such obstacles by allowing them to make out a prima facie case with a showing of continued absence from jury panels of members of the class allegedly discriminated against. E.g., Patton v. Mississippi, 332 U.S. 463, 466 (1947). See generally Note, State Jury Selection Procedure Held a Violation of the Fourteenth Amendment, 1967 DUkE L.J. 346, 348.49 n.18. 
traditionally subject to prejudice and oppression. ${ }^{86}$ Defendants not themselves of an oppressed class, or those alleging exclusion of a class different from their own, were required to establish actual prejudice to their position at trial in order to obtain reversal of convictions by such juries. The difficulty of making an adequate showing of prejudice effectively restrained the defendant's right to trial by a jury representing a cross-section of the community. 87

The stringency of the prejudice requirement was well documented in Fay $v$. New York, ${ }^{88}$ in which labor leaders convicted of extortion raised due process and equal protection challenges to New York's blue ribbon juries, from which the laboring classes, women, and capital punishment objectors were excluded. Emphasizing that the defendants were not of the same class as the excluded jurors, the Supreme Court required that they show, for reversal of their convictions, that the exclusions prejudiced them below. ${ }^{89}$ The Court concluded that no prejudice was shown and affirmed the conviction, positing that a different jury would probably have decided the case the same way. In effect, the blue ribbon jury was held to be sufficiently representative of a cross-section of the community.

The prejudice requirement is of greatest concern to a petitioner with an equal protection argument, since a holding that a procedure is violative of due process is the equivalent of holding that prejudice will occur to the rights of any defendant receiving the same treatment subsequently.90 A defendant making an equal protection argument, however, will succeed only if he can show that the procedure was unfair as to him individually, unless he can qualify under the same class rule, in which case prejudice is presumed. Because of the in-

${ }^{80}$ Hernandez v. Texas, 347 U.S. 475, 477-78 (1954); Note, The Defendant's Challenge to a Racial Griterion in Jury Selection: A Study in Standing, Due Process and Equal Protection, 74 YaLE L.J. 919, 920-23 (1965).

${ }^{87}$ For a discussion of the restrictive scope of the "cross-section" concept, as well as a comparison with "cross-section" in the federal court system, see generally Note, State Jury Selection Procedure Held a Violation of the Fourteenth Amendment, 1967 DUKE L.J. 346, 350-56 \& nn.25.53.

s8 332 U.S. 261 (1947), noted in 16 FordhaM L. REv. 276 (1947) and 33 VA. L. Rev. 655 (1947).

${ }^{80} 332$ U.S, at 293.

${ }^{\circ}$ See Note, The Defendant's Challenge to a Racial Criterion in Jury Selection: A Study in Standing, Due Process and Equal Protection, 74 YALE L.J. 919, 936-38 (1965). See generally Sedler, Standing to Assert Constitutional Jus Tertii in the Supreme Court, 71 YALE L.J. 599, 636-38, 658-59 (1962). 
dividualized nature of the equal protection claim, the precedential value of an equal protection reversal is limited. Therefore, it is reasonable to conclude that the equal protection clause is at best an inadequate tool for achieving the goal of cross-sectional jury representation in every case.

The inherent limitations of an equal protection approach to jury selection procedures seemed to have been alleviated by Labat $v$. Bennett, ${ }^{91}$ a recent due process decision by the Court of Appeals for the Fifth Circuit presaging a new approach to state jury selection practices. In a decision reversing the convictions of two Negroes who were tried by a jury from which daily wage earners were liberally excused to expedite the selection of veniremen, the court held the daily wage earner exclusion to be a denial of both due process and equal protection. While noting that the daily wage earner category encompassed a large part of the Negro community, the Fifth Circuit nonetheless declined to base its decision solely on a finding of racial discrimination, but held additionally that the exclusion of daily wage earners from the venire sufficiently abridged the cross-section of the community as to constitute due process and equal protection violations. ${ }^{92}$ Implicitly, the court thus removed the necessity for a class to be one traditionally subject to bias and oppression before its exclusion would produce an unconstitutional jury. Additionally, by approving citations of state court decisions in which petitioners had successfully attacked the exclusions of classes of which they were not themselves members, ${ }^{93}$ the court indicated its intention to allow any defendant to challenge the composition of a jury from which community members were erroneously excluded. This abandonment of the traditional equal protection analysis and of the actual prejudice requirement was accomplished by raising the more refined equal protection considerations to the magnitude of due process rights.

Holding, in effect, that due process requires a meaningful cross-

${ }^{01} 365$ F.2d 698 (5th Cir. 1966), cert. denied, 386 U.S. 991 (1967), noted in Note, State Jury Selection Procedure Feld a Violation of the Fourteenth Amendment, 1967 DuKE L.J. 346.

${ }^{82} 365$ F.2d at 719-20.

${ }^{93}$ E.g., State v. Madison, 240 Md. 265, 213 A.2d 880 (1965). The Madison court allowed a defendant to challenge the exclusion of those who would not state a belief in God. The court held the exclusion to be a violation of due process. Also approvingly cited is Allen v. State, 110 Ga. App. 56, 137 S.E.2d 711 (1964), which held, in allowing a white civil rights worker to challenge the cxclusion of Negroes, that a jury not repre. sentative of the community denies due process to any defendant. 365 F.2d at 723 . 
section of the community, the court attempted to implement this theory by requiring that jury exclusions be evaluated against a threefold test: the exclusion must be related to juror competence; or it must be related to community need; and it must not unduly abridge the concept of cross-section. ${ }^{94}$ Implicit in this test is a new approach to state jury exclusions. Although the interaction of the components of the triple test was not clearly delineated by the Labat court, ${ }^{95}$ it seems clear that the cross-section requirement serves as a limitation on justifiable exclusions for competence and public need; therefore, even acceptable categories of jury exclusions must not be so overinclusive as to vitiate the cross-section. An approach which thus concedes the primary importance of the cross-section wholly undercuts the validity of the state's former justification that the jury used was arguably impartial, and therefore it did not matter that there were other community members, arguably similarly impartial, who were not allowed to serve. The Labat rejoinder is that the state must show an acceptable justification for their exclusion. That the crosssection requirement should function as a limitation on jury exclusions seems soundly justified by its inherent ability to assure the presence of many community viewpoints, and, in the context of the unanimity requirement, a community standard. ${ }^{96}$

\section{Impact of Labat v. Bennett on Gapital Punishment Ghallenges}

To what extent, then, does a reasonable necessity exist under the Labat tests to exclude objectors to capital punishment from juries through challenges for cause? ${ }^{\text {?t }}$

First, the Labat standards for jury selection will have no impact on the challenge for objection to capital punishment if that case is restricted to regulating venire selection only. ${ }^{98}$ However, it is reasonable that those standards should extend to the state's challenge for cause exclusion. It would afford a defendant little comfort to be

\footnotetext{
04365 F.2d at 723.

of For a discussion of the possible interactions among the three branches of the test see Note, State Jury Selection Procedure Held a Violation of the Fourteenth Amendment, 1967 Duke L.J. 346, 359-63.

"For a discussion of the importance of ensuring that the jury represent a community standard see text preceding note 36 supra.

${ }^{\circ}$ See generally Note, Allowing Challenge for Cause to a Prospective Juror Opposed to Capital Punishment, 45 N.C.L. REv. 1070 (1967).

${ }^{\circ 9}$ The Fifth Circuit's decision in Labat is, of course, not binding on courts of other circuits or jurisdictions, but is persuasive only.
} 
granted a truly representative venire, if the grounds for challenge authorized by the state and utilized by the prosecutor could effectively disfigure the venire before the actual jury were impanelled. Analogously, it is established that a state may not justify its selection system ${ }^{9 \theta}$ by showing the presence of a representative general venire, when it has subsequently employed a procedure which strips all Negroes from the group before the final venire is presented to the state and the defendant. ${ }^{100}$ In Eubanks $v$. Louisiana ${ }^{101}$ the Supreme Court overturned such a system, holding that the individual selection of jurors for the final venire by the judge rather than by random drawing was unconstitutional. ${ }^{102}$ The jury selection system under litigation in Labat involved primarily the use of volunteers for the final venire. Though a volunteer system would seem not to discrimmate unfairly against any class, the record did not indicate the number of Negroes which actually volunteered. ${ }^{103}$ Even such an apparently non-discriminatory plan as this was effectively condemned when the Fifth Circuit refused to accept the stipulation of the parties that there was a ten percent representation of Negroes on the general venire, and looked instead to the much smaller representation afforded them on the final voluntary venire. ${ }^{104}$ The implication is

99 The general venire may be, for example, a card file of names of prospective jurors culled from the city directory or a similar source. Possibly the prospects will have been interviewed, and those not meeting statutory standards or claiming some personal hardship will have been excused before the file is assembled. This compilation of names may number in the thousands, and from it a more manageable number is sometimes selected for use during the current year. However, grand jury venires will at some point be taken out of this group, and petit jury venires will similarly be selected for the various divisions of the local criminal court. These proposed petit jury venires may be further refined before a final venire is presented to the parties before trial. Thus, many selective steps intervene before the final venire is assembled. However, the defendant (and the prosecutor) have effectively at their disposal only that cross-section of the community which survives the culling process. Tine complexity of the procedure is detailed in Labat v. Bennett, 365 F.2d 698, 713.15 (5th Cir. 1966).

${ }^{100}$ E.g., Eubanks v. Louisiana, 356 U.S. 584 (1958) (jurors were individually chosen to serve); Smith v. Texas, 311 U.S. 128 (1940) (Negro prospective jurors placed at the bottom of the hist to be called); Scott v. Walker, 358 F.2d 561 (5th Cir. 1966) (Negroes removed from panel by assignment to grand jury); see Swain V. Alabama, 380 U.S. 202, 222-24 (1965) (dictum) (Negroes removed by prosecutor on peremptory challenge).

101356 U.S. 584 (1958). The selection procedure under litigation in Eubanks was the same as that involved in Labat. See note 99 supra.

${ }^{102}$ Intentional discrimination was conclusively presumed in Eubanks when it was established that Negroes had seldom, if ever, sat on a criminal jury panel which was composed by personal selection rather than random drawing.

108365 F.2 $\mathrm{d}$ at 715.

${ }^{104} I d$, at 716-17. 
that any procedure which results in excluding the classes discriminated against from actual jury service is constitutionally unacceptable. ${ }^{105}$ Because of Labat's decree that the classes so protected are not now limited to the victims of traditional discrimination but encompass all community segments for whose exclusion no reasonable necessity exists, ${ }^{106}$ and since a state may not accomplish through indirection what it may not constitutionally do overtly, the bearing of Labat and the jury exclusion cases on the state's system of challenges for cause is evident. Those classes which may not be excluded in the venire selection procedure may similarly not be excluded through challenges for cause, subject only to the continuing requirement that challenges be allowed on any showing of actual partiality. ${ }^{107}$

Requisite to the applicability of the Labat standards is the exclusion from jury service of an identifiable class. In everyday parlance, the word "class" denotes a group of recognizable size with a common characteristic; and, on the basis of similar beliefs in the inutility of the death penalty, capital punishment objectors might legitimately be deemed a class. Historically, however, two narrower tests had to be satisfied before a particular group's inclusion on juries under the "cross-section of the community" standard was required: it must be one whose exclusion was not reasonably related to the end of assembling an impartial jury, and it must possess some degree of cohesiveness. ${ }^{108}$ Under the "reasonable relation" approach, for example, it has been held proper to exclude lawyers, who, as officers of the court, have a "public interest" in the trial;100 minors, who, vis-à-vis adult defendants, do not represent a community cross-section since they are "a wholly foreign group un-

\footnotetext{
${ }^{105}$ Formerly, case law bore out the proposition that any procedure which had the result of excluding the classes discriminated against, if their absence was not explained by some reason other than invidious discrimination, was unconstitutional. See, e.g., Arnold v. North Carolina, 376 U.S. 773 (1964); Eubanks v. Louisiana, 356 U.S. 584 (1958); Hernandez v. Texas, 347 U.S. 475 (1954); Avery v. Georgia, 345 U.S. 559 (1953); Cassell v. Texas, 339 U.S. 282 (1950); Hill v. Texas, 316 U.S. 400 (1942); Smith v. Texas, 311 U.S. 128 (1940); Pierre v. Louisiana, 306 U.S. 354 (1939); Norris v. Alabama, 294 U.S. 587 (1935); Neal v. Delaware, 103 U.S. 370 (1880).

${ }^{100}$ See text accompanying notes $92-93$ supra.

${ }^{107}$ As challenges for cause are necessary to remove biased jurors, the right to such challenges is of constitutional magnitude. See note 51 supra.

108 Note, 38 Miss. L.J. 508, 511 (1967). For a discussion of the "class" concept in the federal courts see Note, The Congress, The Court and Jury Selection: $A$ Critique of Titles $I$ and II of the Civil Rights Bill of 1966, 52 VA. L. REv. 1069, 1131 \& $\mathrm{n} .324$ (1966).

${ }^{100}$ Harrison v. State, 231 Ind. 147, 160, 106 N.E.2d 912, 919-20 (1952).
} 
related to the adult stream . . .;"110 and those without an eighth grade education, as the education level achieved to some extent reflects intelligence. ${ }^{111}$

Exemplary of classes held not to possess a minimum amount of "cohesiveness" are non-voters, who are unified only by apathy. ${ }^{112}$ However, a recent case held that those who would not affirm a belief in God constituted a class which could not constitutionally be eliminated from jury panels. ${ }^{113}$ Another court, although holding that those aged twenty-one to twenty-five were not a cognizable class, ${ }^{114}$ seemed to base its decision not so much on the incohesiveness of the class as upon the fact that it was not expected that they would represent a community viewpoint different from that of eligible citizens. Thus, the cohesiveness element appears to require that class members possess more-than-casual, common identifying characteristics, which may be found in the stance assumed by the class on religious, political, or community matters.

It is precisely a unique community viewpoint which identifies capital punishment objectors, like non-believers, as a cohesive class. Indeed, empirical research is beginning to verify the uniqueness of viewpoint held by capital punishment objectors. Thus, recent studies indicate that those who favor and those who oppose capital

${ }_{110}$ George v. United States, 196 F.2d 445, 454 (9th Cir. 1952).

111 United States v. Henderson, 298 F.2d 522, 524-25 (7th Cir.), cert. denied, 369 U.S. 878 (1962). The first two branches of the Labat triple test-public need and competency-subsume the considerations which formerly were directed to determine whether an exclusion had a "reasonable relation" to the assembly of a proper jury. However, the cross-section requirement emphasized by Labat limits exclusions secm. ingly justifiable under public need and competency if those exclusions makc noticeable inroads upon the representativeness of the panel. Therefore, an education requirement, for example, might be invalid under the Labat test if it eliminated from jury service a large percentage of the population, even though an education requirement would meet the old qualification of "reasonable relation." Thus, it follows that the "reasonable relation" approach has been heavily modified, and its precedents croded, by the triple test in Labat.

${ }^{112}$ See United States v. Greenberg, 200 F. Supp. 382 (S.D.N.Y. 1961). The petitioner in Greenberg attempted to construct a political classification for non-voters: the "politically dormant."

${ }^{113}$ See note 93 supra. The court noted that the statute authorizing the cxclusion of non-believers had been held violative of the first amendment. Thereforc, trial by juries selected in accordance with this unconstitutional statute was a violation of duc process, requiring reversal of a conviction without the necessity for proving prcjudice. State v. Madison, 240 Md. 265, 273-74, 213 A.2d 880, 885 (1965). Though the result of the decision is to render non-believers an improper class for exclusion, the reasoning of the case is not primarily directed toward establishing guidelines for class definition. Rather, it was assumed that non-believers form a class.

114 King v. United States, 346 F.2d 123 (1st Cir. 1965). 
punishment differ on a complex of values, including the approach they take not only to punishment but also to the process of initial guilt determination. ${ }^{115}$ In the past, the allegation that juries qualified on the capital punishment question were more prone to convict than others has met with no success in the courts; ${ }^{116}$ however, in no case yet decided has support for this contention been sought from the bulk of material which is beginning to emerge on the question. For example, in Fay $v$. New York ${ }^{117}$ the Supreme Court acknowledged that its reluctance to strike down blue ribbon juries arose from an unwillingness to concede, in the absence of evidence, that the viewpoint of the excluded working classes would have produced a significantly different result from that reached by the more privileged groups represented on the panel. ${ }^{118}$ However, the necessity for presenting sociological studies of the unique community viewpoint held by capital punishment objectors will diminish if the expanding concept of proper jury representation introduced by Labat draws further support, for the rationale of that case posits that members of those groups who might have an individual viewpoint representative of a cognizable segment of the community must be included as jurors, unless their absence is justified. ${ }^{119}$ Under such a communityviewpoint test, capital punishment objectors are a necessary class for jury inclusion. This result is well adapted to the continuation of

${ }^{116}$ See Oberer, Does Disqualification of Jurors for Scruples Against Capital Punishment Constitute Denial of Fair Trial on Issue of Guilt?, 39 TEx. L. Rev. 545 (1961). Mr. Oberer's conclusion is that a jury qualified on the capital punishment issue would be more likely to convict, and that due process was abridged by trial by a jury stripped of "the most humane of its prospective members." Id. at 549. "[T]he death penalty qualification of the jurors, in order to provide the prosecutor with an 'impartial' jury on the issue of punishment, denies to the defendant, as a corollary, a similarly impartial jury on the more basic issue of guilt or innocence." Id. at 547. Mr. Oberer wrote, however, without the supporting structure of case law, culminating in Labat, on the expanding concept of cross-section.

${ }^{110}$ E.g., Fay v. New York, 332 U.S. 261, 273 (1947); Turberville v. United States, 303 F.2d 4.11, 420.21 (D.C. Cir.), cert. denied, 370 U.S. 946 (1962). In granting certiorari in State v. Bumpers, 270 N.C. 521, S.E.2d 173 (1967), cert. granted, 389 U.S. 1034 (1968), the Court has agreed to consider the constitutionality of the challenge for cause to capital punishment objectors. As Bumpers did not receive the death penalty, however, his contention that the challenge violated his due process rights necessarily rests on an assertion that those who do not disfavor capital punishment are more prone than others to convict. See Brief for Defendant-Appellant at 13-14, State v. Bumpers, supra.

${ }^{117} 332$ U.S. 261 (1947).

${ }^{118}$ Id. at 291-92.

${ }^{110}$ See Labat v. Bennett, 365 F.2d 698 (5th Cir. 1966); text accompanying note 108 supra. 
the basic jury function of bringing to the adjudicative process the standards of the community. ${ }^{120}$

Once qualified as a class which is properly part of the community cross-section, capital punishment objectors are a class for whose exclusion no reasonable necessity exists under the Labat tests, which might be considered further refinements on the "reasonable relation" test for identifying classes which may properly be excluded. The "public need" category of exclusions is concerned with the isolation of those occupational classes whose uninterrupted performance of their normal services for the community is deemed more vital than their participation as jurors. Firemen might be an example. Since capital punishment objectors may be scattered throughout many occupational categories, their exclusion is obviously not justifiable on the basis of "public need." Therefore, if such an exclusion is acceptable at all, it must be founded upon the "competency" criterion. The rhetoric directed at justifying the exclusion on this ground has dwelt on the alleged probability that jurors with scruples will not be fair to the state's case. Thus, when the jury is given the opportunity of choosing life or death, a juror committed not to choose death may deprive the state of a sanction. ${ }^{121}$ However, this rhetoric is probably resorted to in aid of a more practical concern that capital punishment objectors would conceivably deadlock a jury operating on the Andres requirement of juror unanimity on punishment even though unanimity as to guilt had been achieved. ${ }^{122}$ This objection could be met by propounding a voir dire question-narrower than that generally used-distinguishing among varying degrees of opposition to capital punishment. If there is any kind of case in which a juror admits that he would be willing to return a death verdict, it is not capital punishment to which he objects, but rather its unrestrained application. However, the questions often propounded on voir dire inquire only as to whether the juror holds any conscientious opinions, or scruples, regarding capital punishment. Arguably, any layman confronted with that question will say he has scruples if he is somewhat unhappy about death sentences. However, a general question as to the presence of mere reservations is

\footnotetext{
120 See note 36 supra and accompanying text.

${ }_{131}$ See People v. Riser, 47 Cal. 2d 566, 305 P.2d 1 (1956), cert. denied, 353 U.S. 930 (1957).

${ }^{122}$ See cases discussed in text accompanying notes 68-74 supra.
} 
far from the inquiry which separates those who would never vote for the ultimate penalty from those who would reserve it for the direst cases. Such differentiation could be accomplished by more definitive questioning, after which one who steadfastly refused ever to impose death could be excused as incompetent, since he could not accord to the state the benefit of a sanction legislatively provided. All others, however, satisfy the competency test and are not committed to deny the state a sanction prior to hearing the case. Their exclusion from the community cross-section through an overinclusive classification created by a general voir dire question is clearly improper under the due process standard of Labat.

As a greater spread of community sentiment becomes represented on juries, it is likely to produce added expense of judicial time and effort resulting from the operation of the unanimity requirement. However, the spectre of hung juries is an avoidable evil if statutes are drafted to require that death sentences be unanimous, but that life imprisonment be imposed upon jury disagreement as to punishment. ${ }^{123}$ Furthermore, if numbered among the jurors there is none who would refuse ever to impose death, the ultimate sanction could continue to be applied for the graver offenses. Because the "right" of the state to the death penalty could be otherwise assured, those prospective jurors who merely state some degree of opposition to the death penalty are not a class for whose exclusion a reasonable necessity exists. Their absence, therefore, denies the defendant the benefit of trial by a representative cross-section of the community.

\section{CONCLUSION}

By a modification of voir dire questioning, the continuation of capital punishment, an alternative which the states apparently wish to preserve, may be reconciled with the advancing constitutional re-

\footnotetext{
${ }^{128}$ The Andres decision seems, in dictum, to preclude Congress from drafting a statute to provide life imprisonment upon jury disagreement over the death sentence. See notes 17-22 supra and accompanying text. However, under a federal statute allowing a jury to recommend life imprisonment by less than a unanimous vote, no constitutional challenge could be made under the Andres standard. It is verdicts which must be unanimous; however, recommendations by the jury as to life imprisonment could be judicially construed as separate from the verdict, so that the unanimity requirement is obviated for such recommendations. For example, no case in North Carolina lias decided whether unanimity is required on life imprisonment under the operative state statute providing a choice between life or death. The strongest intimation is that the North Carolina statute is to be given the same con-
} 
quirements for jury selection and with the historic function of the jury as representative of contemporary community standards. On voir dire, it will be necessary to formulate specific questions designed to uncover degrees of opposition felt by the juror who states some scruple. To confine most tightly the class to be excluded, the question might properly be: "Mr. Juror, could you under any circumstances impose capital punishment?" Those persons answering in the negative could then be challenged for cause by the state. In addition, if the prosecutor elects, he could direct his peremptory challenges to those who state some degree of opposition short of disqualification. But no longer should a blanket exclusion apply to all those community members who participate in a generalized hesitation about the wisdom of death sentences.

struction favored in Andres. See State v. Childs, 269 N.C. 307, 152 S.E.2d 453 (1967) (relying on the Puff case). However, a specific future holding to the contrary is not precluded by North Carolina case history. 